\title{
THE CRETACEOUS-TERTIARY BOUNDARY IN THE CONTEXT OF IMPACT GEOLOGY AND SEDIMENTARY RECORD - AN ANALYTICAL REVIEW OF 10 YEARS OF RESEARCHES IN BRAZIL*
}

\author{
PAULO PEREIRA MARTINS JR. ${ }^{1}$, GILBERTO ATHAYDE ALBERTÃO ${ }^{2}$ AND RENATO HADDAD ${ }^{3}$
}

\begin{abstract}
The question of the Cretaceous-Tertiary (K-T) boundary is here considered in a more wide sense, considering its importance for Impact Geology. The first two sub-principles of uniformitarianism can be seen as similar to the actualist principle and can be both merged with catastrophism as a renewed view of geosciences [as two principles in dialectical opposition for working with regime $x$ rupture processes in Earth Sciences]. Examples from Brazilian basins, especially Pernambuco-Paraiba (PE-PB) basin, are considered with their face value for the study of the K-T boundary. Most of their characteristics also give support to Impact Geology Theory. It is also considered the importance of the initial works on the Brazilian K-T sedimentary boundaries (in a Impact Geology context), which begun 10 years ago giving support to present time trends of researches. At present with the actual state of knowledge in Geosciences it is no longer possible to consider the Earth System as a closed one (Albertão 1991). It is obvious that Earth is an open system subjected to any sort of interactions with other corpses and fields within the Cosmos as many geological and biological evidences indicate everywhere.
\end{abstract}

Keywords: K-T boundary, sedimentary record, epistemology, Historical Geology, catastrophes, Pernambuco-Paraiba basin, Campos basin, iridium anomaly, impact craters.

\section{AN EPISTEMOLOGICAL}

INTRODUCTION "Catastrophes are part and parcel of uniformity" - This was certainly T. H. Huxley's final statement (1869, p.xlvii) concerning Lyell's principle of uniformity (Lyell 1830-1833). Also J. Le Conte (apud Hooykaas 1970) declared "Catastrophism and uniformitarianism are opposite extremes which must be combined and reconciled". Both are statements of a comprehensive understanding of Earth's history and vicissitudes all along its whole existence. Lyell's understanding of these questions (letter of 1829) corresponded to a "steady state conception" for Earth history - "no causes whatever have ... ever acted, but those now acting" (in Lyell 1881, p.234).

For more than 150 years a significant part of the community of people of science, mostly geologists of the Anglo-Saxon tradition, maintained loyalty to a rather rigorous attachment to the [doctrine of uniformity], which excluded [catastrophes as meaningful events] in whole Earth's history. Early XIX century researchers accepted the catastrophic point of view as one basic principle for geological sciences. The Phaenerozoic geological standard column was established with this sort of view sometime before and a little later than Lyell's publication of his "Principles of Geology" in 1830. Lyell denied any sort of catastrophic event and considered it practically nonsense.

In spite of some discordant voices the geological community followed the uniformitarian view with orthodoxy presenting sometimes very bad examples of what should not be done with science and with scientific colleagues within a [project of knowledge] which is really concerned with truth. Marvin (1990) indicates some illustrations on this question: (i) in 1891, Gilbert's self-control concerning the interpretation of Meteor crater in Arizona (USA) as a derived impact crater restrained Impact Geology for almost 60 years although D. M. Baringer had collected evidences for impact in this same crater by 1905; (ii) Ralph B. Baldwin found difficulty in publishing papers on lunar craters; (iii) The scablands geomorphology in Oregon State was recognised as a catastrophic event of basalt extrusion inside a thick blanket of ice of the last glacial episode. The results of the author's conclusions on the scablands morphology were certainly painful for him who suffered exclusion from the community of geologists. A social fact like this is very important to remind us of the dangers of any sort of authoritarian thinking in science and in whatever human activities. Inadequate social control and self-imposed control are two faces of the same authoritarian aspect in human affairs.

The Tunguska event in Siberia in 1908 offered an occasion for a long history of research looking for a comprehension of the meaning of an usual event. Some Russian researchers achieved a recent successful modelling of the event - a $30^{\circ}$ entry of a bolide in the atmosphere with the explosion occurring high in the atmosphere. In Brazil a similar event happened in Amazonas State near São Paulo de Olivenca, Rio Curaca a tributary of Rio Javari, itself a tributary of Rio Solimoes (August 13 ${ }^{\text {th }} 1930$ ). Three bolides struck into/over or above the forest - a Tunguska average size bolides of 10-100 $\mathrm{m}$ as lately reported in Daily Telegraph (6 March, p. 9, 1931) from a previously report in L'Osservatore Romano by Father Fidello (1930).

Man arrival on Moon with the Apollo flight mission in the early 1970 permitted to recognise that the Moon's craters are definitely impact-derived products. So must be with Earth's many craters no matter if they are partially preserved, non preserved at all or eventually underlying some thick sedimentary deposit. Alvarez et al. (1980) presented a definite proof for this long run epistemological problem in Geology with their discovery of the final event, which gave an end to the whole phase of evolution of the Mesozoic Era.

Lyell's [uniformitarian principle] is recognised as divided in [four sub-principles]: [1] the methodological principle considers the invariance of matter and energy properties and natural laws in time (Gould 1965) [2] the causal principle considers the invariance of the types of geological processes during time having present day geological processes as the only ones in whole Earth's history [3] the actional principle considers the invariance of geological processes energy ratios around averages throughout the whole history [4] the configurationalprinciple is Lyell's theory alleging temporal uniformity of crust and life as a steady-state view of geological conditions through time (Austin 1979). Of course the $4^{\text {th }}$ sub-principle is denied by the very geological facts. Notwithstanding many geologists still keep in mind the strict mental habit of rigorously applying this $4^{\text {th }}$ principle to whatever model of crustal evolution. An example is the systematic application of plate tectonics typically a Mesozoic-Cainozoic event structuring to times as older as the Proterozoic. Of course Tectonics is Tectonics but as a broad phenomenon it underwent different phases with different styles and different energy involved in the geological processes.

Not every school of thought in Geology agrees with the validity of the totality of the four sub-principles (Austin 979). In continental Europe the actualist principle (Prevost 1825, 1845) has a correspondence only to the first two sub-principles. Actualism (Hooykaas 1970) is considered here as the guiding principle which can comprise together both the actualist principle in a dialectical opposition with a catastrophist principle with all its modern variations like episodic sedimentation (Dott 1983). Actualism constitutes with the [regime vs. rupture aspects] a true and definitive principle for Geosciences. Amidst traditional actualist catastrophists were Elie de Beaumont (1798-1874), L. Frapolli (1846-47) and Charles Saint Claire Deville (1814-1881) (apud Hooykaas 1970). Dott (1983) himself is an example of a man of science still reacting to prejudices against catastrophism in his paper's item "Why not catastrophic sedimentation? "Catastrophic ... should be purged from our vocabulary because its use feeds the creationist-neocatastrophist cause." (in Dott 1983, p.9). There is no sensible way of purging this word out from our vocabulary for there is not in any western language a better word than this Greek one - it means exactly what it means.

\footnotetext{
1 - Fundação CETEC, Av. J. C. da Silveira 2000, Horto, 31170-000 Belo Horizonte, MG and Univ. Fed. de Ouro Preto, Escola de Minas, Morro do Cruzeiro, 35400-000 Ouro Preto, MG, Brasil. E-mail: pmartin@cetec.br

2 - PETROBRAS/EPBC, Av. Elias Agostinho, 665- Ponta da Imbetiba, 27913-350 Macaé, R.J, Brasil. E-mail: Albertão@ep-bc.petrobras.com.br

3 - Fundação CETEC, Av. J. C. da Silveira 2000, Horto, 31170-000 Belo Horizonte, MG
} 
The year of 1995 was a decisive one with Shoemaker-Levy comet impact on Jupiter. Theoretical and practical approaches to Impact Geology became a definitive scientific branch of science from then on (decade of 1990). It was witnessed that the comet Shoemaker-Levy, which was divided in nine enormous pieces by the extraneous shearing gravitational force of planet impacted on it one by one. One of those impacts produced a disturbance in Jupiter atmosphere as bigger as planet Earth. This historical aspect is very old in Solar System and Table 1 presents some fairly good probabilistic estimations of impact ratios in Archean, Proterozoic and Phaenerozoic Eons.

Table I - A broad view on the probabilities of catastrophic impacts cratersyielding on Earth [4.6 Byr-Recent].

\begin{tabular}{|c|c|c|c|c|}
\hline $\begin{array}{l}\text { Probability density of } \\
\text { impacts on Earth }\end{array}$ & Age or phase & $\begin{array}{l}\text { Craters diameters } \\
\text { De }\end{array}$ & $\begin{array}{c}\text { Pussible } \\
\text { number of } \\
\text { cracters }\end{array}$ & Authors \\
\hline $1.4 \times 2.45 \times 10^{-1} \mathrm{~km}^{-2}$ & & $>16 \mathrm{~km}$ & & Barlow ly9o \\
\hline & $4.6-3.9 \mathrm{Byr}$ & $\begin{array}{l}>100 \mathrm{~km} \\
>1000 \mathrm{~km}\end{array}$ & $\begin{array}{c}2500-3000 \\
25\end{array}$ & Griew 1980 \\
\hline & $\begin{array}{l}3.8-3.2 \mathrm{Byr} \\
3.2-1.1 \mathrm{Byr} \\
11.1 \mathrm{Byr}\end{array}$ & $\begin{array}{l}>30 \mathrm{~km} \\
>30 \mathrm{~km} \\
>30 \mathrm{~km}\end{array}$ & $\begin{array}{c}>31150 \\
>1650 \\
825\end{array}$ & Wilhelms 1987 \\
\hline $0.45( \pm 0.2) \times 10^{-14} \mathrm{yr}^{-1} \mathrm{~km}^{-2}$ & Proterozoic & $>20 \mathrm{~km}$ & & $\begin{array}{l}\text { Shoemaker and } \\
\text { Shoemaker } 1990\end{array}$ \\
\hline $0.35( \pm 0.13) \times 10^{-14} \mathrm{yt}^{-1} \mathrm{~km}^{-2}$ & Phitenerozoic & $>20 \mathrm{~km}$ & & Grieve 1982 \\
\hline
\end{tabular}

Since 1978 in Historical Geology classes for the undergraduate course of Engineering Geology of Ouro Preto Federal University (School of Mines), students' attention was stimulated to the important fact that Geology is a [pro-historical] science [pro-] in a strict epistemological sense and historical in an [analogous sense] but not in a strict similar sense to human historical sciences (Martins Jr. 1999). A non-prejudiced researcher must expect to witness that some of the transformations on Earth's crust and/or within the biospheres (in the sense of Termier and Termier 1986; Table 2) must have also been provoked by catastrophic events of widespread importance in spite of Lyell's idiosyncratic denial of them. The traces of these many transformations are evident in the geological record. These various types of evidences are [attributes of historicity] of the geological record. Epistemologically a "historicity-attribute" means any significant and conspicuous aspect as registered in the geological record, which permit to decide about the evolutionary direction of events and their styles.
BRAZILIAN MESOZOIC-CAINOZOIC TRANSITION SEDIMENTARY RECORD - TEN YEARS OF RESEARCHES (1990-2000) The first complete works dealing with the stratigraphy and biostratigrapy of the outcrops of PE-P basin were those of Tinoco (1967), Beurlen (1967), Mabesoone et al. (1968) and more recently Stinnesbeck (1989). They can be considered the pioneers on the K-T boundary matter. It's also important to quote Sircilli Netto's work (1986), who was the first one trying to determine an Ir-anomaly in Brazilian marginal basins although unsuccessfully. Since 1978 on, an epistemological effort for Historical Geology teaching and researches (at Ouro Preto Federal University) evolved step by step determining a philosophy and a structure for a research programme [empirical and epistemological].

Only by the year of 1990 the search for a possible K-T boundary impact evidences inside any of the Western Atlantic marginal basins became a defying aspect, which interested us mostly. Historicityaspects like fossils extinction, Ir-anomaly, sedimentary evidences of a crisis, faunal/pollens change from underlying and upper strata in K-T boundary, spherulids/tektites and shocked quartz were expected to be recorded in this Brazilian and eventually other sedimentary basins within the K-T boundary. In a calculated risk at that time we started working with this subject in the M.Sc. degree programme of Ouro Preto Federal University (School of Mines). It was a well-succeeded research by 1993 (Albertão 1993). This effort opened a new prospect of researches in Brazil.

PERNAMBUCO - PARAIBA (PE-PB) BASIN IN NORTHEASTERN BRAZIL (PERNAMBUCO STATE) Impacts can provoke systemic phenomena on Earth's surface, which can only be well understood with an interdisciplinary approach. In this respect the Final Mesozoic planetary event is focused from its "local historicityaspects" in coastal PE-PB basin (Fig. 1) and submarine Campos basin. Many detailed studies were conducted concerning micropalaeontology [plankton and pallinomorphs], stratigraphy, Ir-anomaly, geochemistry (stable istopes, rare-earth and other elements distribution), palaeoecology, palaeosurface dynamics, climatology and diagenesis in PE-PB basin, especially the areas of Ponta do Funil and Poty Quarry (Albertão 1993, Albertão et al. 1993, Albertão et al. 1994a, 1994b, Albertão and Martins Jr. 1996a, 1996b).

The K-T boundary and micropalaeontology Micropalaeontology was determinant to characterise the alterations from

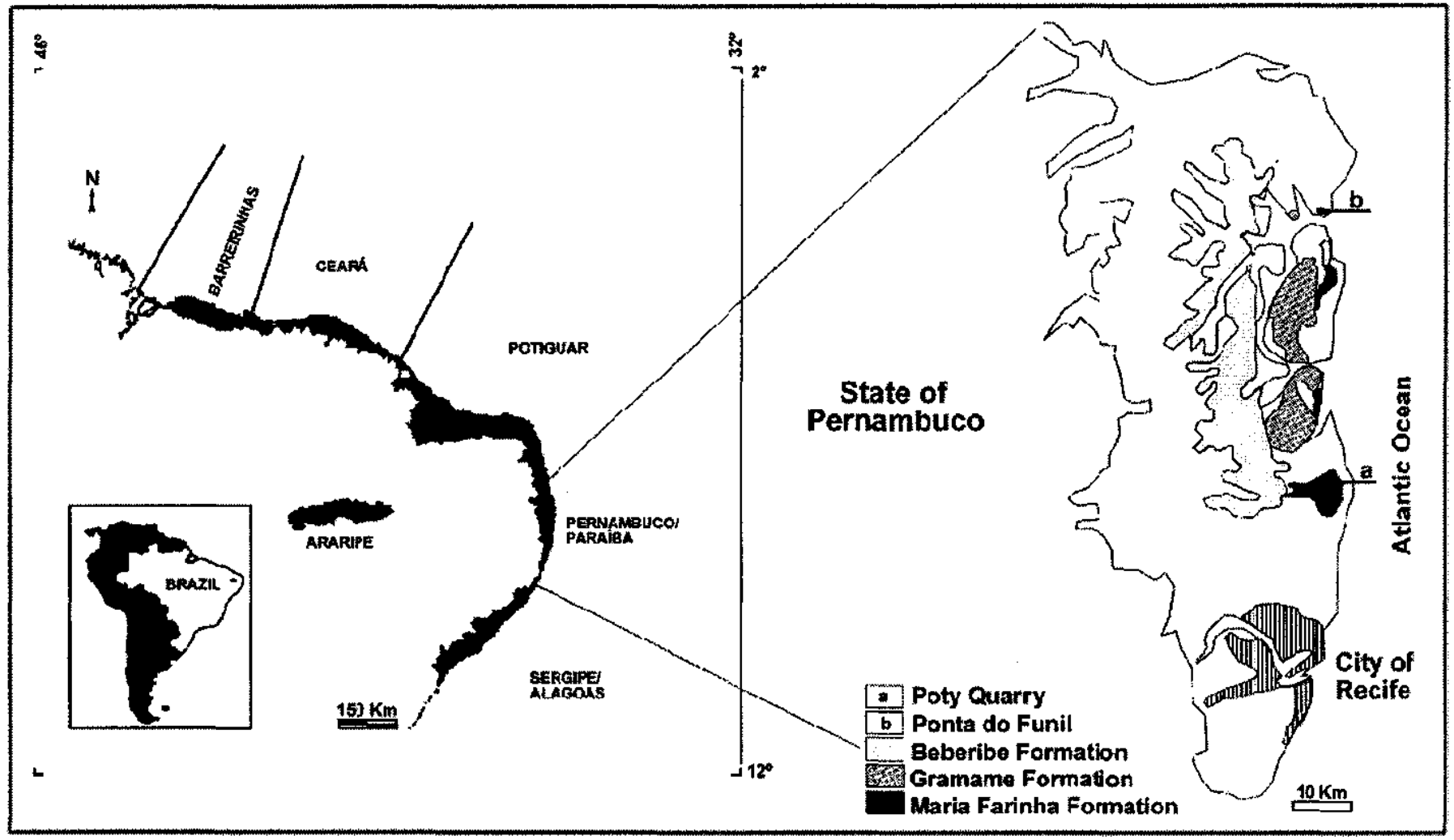

Figure 1 - Location map for Pernambuco-Paraiba basin. Poty quarry is indicated. 
Table 2 - "The many biospheres" concept and the biospheres characteristics accordingly to Termier and Termier (1980), modified by the present authors; geological dating are from various sources.

\begin{tabular}{|c|c|c|c|}
\hline Names of Biospheres & $\begin{array}{c}\text { Age } \\
\text { By bil. years }\end{array}$ & Most Important Characteristics & $\begin{array}{c}\text { Events and/ dated craters } \\
\text { and/or tektites }\end{array}$ \\
\hline Pre-biosphere & $4.5-3.8 \mathrm{By}$ & $\begin{array}{l}\text { Intensive pitting; Small emerging continental areas; } 2 \\
\text { atmospheres; the } 1^{\prime} \text { atmosphere ejected by solar T-Tauri } \\
\text { event; } 2^{d} \text { atmosphere was reductive }\end{array}$ & $\begin{array}{c}\text { [ 4.6-1.1 [most intensive } \\
\text { Impact Era on Earth and Moon }\end{array}$ \\
\hline $\begin{array}{l}1^{1} \text { biosphere } \\
\text { Archean }\end{array}$ & $3.5-3.0 \mathrm{By}$ & $\begin{array}{l}\text { Consolidation of the } 1 \mathrm{t} \text { crust under anoxic conditions; } \\
\text { procharyonts micro-organisms; anaerobiose; } \\
\text { archaebacterias. }\end{array}$ & Idem \\
\hline $\begin{array}{l}2^{\mathrm{d}} \text { biosphere } \\
\text { Upper final Archean }\end{array}$ & $3.0-1.75 \mathrm{By}$ & $\begin{array}{l}\text { Crust undergoes } 2 \text { types of consolidation; shields and fold } \\
\text { belts connecting from one pole to other with bacterial life; } \\
\text { photosynthesis; revolution of the atmospheric free } \mathrm{O}_{2} \\
\text { production }\end{array}$ & Sudbury Canada \\
\hline $\begin{array}{l}3^{\mathrm{d}} \text {. biosphere } \\
\text { Proterozoic; Ante- } \\
\text { cambrian }\end{array}$ & $1.75-0.8 \mathrm{By}$ & $\begin{array}{l}\text { Tectonic introduction to Pangea. Two super continents with } \\
\text { a fracture zone almost coincident as the great circle of } \\
\text { Tethys; protocharyonts; pluricellular algae, sexuated } \\
\text { reproduction; eucharyonts chloroplasts; cyanobacterias; } \\
\text { mitochondries; photosynthesis; free oxygen }\end{array}$ & Idem \\
\hline $\begin{array}{l}4^{\text {th }} \cdot \text { biosphere } \\
\text { Ediacarian-Vendian }\end{array}$ & $700-530 \mathrm{By}$ & $\begin{array}{l}\text { Diversification of pluricellular animals; marine } \\
\text { eumetazoans; pelagic ecosystems }\end{array}$ & - \\
\hline $\begin{array}{l}5^{\text {th }} \text { biosphere } \\
\text { Lower Cambrian - } \\
\text { Tommotian }\end{array}$ & $530 \mathrm{By}$ & $\begin{array}{l}\text { Warmer seas with reefs. } 10 \% \text { free } \mathrm{O}_{2} \text {. Pelagic ecosystems, } \\
\text { stromatolites; cyanobacterias, spongiarcheates; eumetazoans } \\
\text { (mollusca, brachiopoda, echinodermata, etc.) trilobites. } \\
\text { Erosion; sedimentation after Assintic movements. }\end{array}$ & - \\
\hline $\begin{array}{l}6^{\text {th }}-7^{\text {th }} \text { biosphere } \\
\text { Middle-upper } \\
\text { Cambrian; Ordivician; } \\
\text { Silurian }\end{array}$ & $\pm 500-400 \mathrm{By}$ & $\begin{array}{l}\text { Opening of the proto-Atlantic, collision orogenesis; Saharan } \\
\text { glaciation; South pole in Africa; Caledonian suture } \\
\text { originates North Atlantic continent; pelagic ecosystems with } \\
\text { acritarchs; reefs, porifera, carnivore cephalopods,; Tethyan } \\
\text { migration of trilobites }\end{array}$ & - \\
\hline $\begin{array}{l}8^{\text {th }}-9^{\text {th }} \cdot \text { biosphere } \\
\text { Upper Palaeozoic; } \\
\text { Lower Triassic }\end{array}$ & 400 till \pm 240 By & $\begin{array}{l}\text { Pangea continent; end of mise en place of the Caledonides; } \\
\text { intracratonic South American basins; Permian massive } \\
\text { extinction; modern atmosphere since then; Variscan } \\
\text { orogenesis; sauropsids, therapsids, reptiles with amniotic } \\
\text { eggs; forests; vertebrate tetrapods, etc. }\end{array}$ & $\begin{array}{l}\text { Permian-Triassic; Araguainha } \\
\text { 40km, Brazil. } \\
365 \pm 7 \text { Siljan }(52 \mathrm{~km}) \\
\text { Sweden. }\end{array}$ \\
\hline $\begin{array}{l}10^{2} . \text { biosphere } \\
\text { Triassic middle-lower } \\
\text { Cretaceous }\end{array}$ & $220-100 \mathrm{By}$ & $\begin{array}{l}\text { Opening of Tethys ocean; Atlantic rupture; appearance of } \\
\text { placentary mammals; angiosperms; archaeopteryx } \\
\text { lithographica; birds; great basalt effusion, etc. }\end{array}$ & $\begin{array}{l}\text { Serra da Cangalha } 220 \text { My } 210 \\
\pm 4 . \text { Manicougan }(70 \mathrm{~km}) \\
\text { Canada; } 183 \pm 3 . \text { Puchezh- } \\
\text { Katunki }(80 \mathrm{~km}) \text { Russia } \\
\end{array}$ \\
\hline $\begin{array}{l}\text { End of the } 10 \text { th } \\
\text { biosphere } \\
\text { Senonian; final } \\
\text { Cretaceous }\end{array}$ & $80-60$ By & $\begin{array}{l}\text { End of Mesozoic Era with meteorite impact in Chicxulub } \\
\text { Yucatan Peninsula; global ecological catastrophe; massive } \\
\text { extinction of Mesozoic fauna and flora; continuous plate } \\
\text { tectonics }\end{array}$ & $\begin{array}{l}\text { Chicxulub eyent } \\
\text { Mesozoic Era ends. } \\
D_{c}=300 \mathrm{~km}\end{array}$ \\
\hline $\begin{array}{l}11^{\text {th }} \text { biosphere } \\
\text { Palaeocene - } \\
\text { Miocene }\end{array}$ & $60-6 \mathrm{By}$ & $\begin{array}{l}\text { Continuous Alpine, Andes and Himalayan tectonics; oceans } \\
\text { increase; earth's magnetic field oscillates; biogeographic } \\
\text { expansion of mammals, birds and angiosperms; plates } \\
\text { separation; extensive new habitats on whole Earth. }\end{array}$ & $\begin{array}{c}\text { Pliocene } 14.7 \pm 07 \\
\text { Moldavites; } 28.6 \pm 2 \text { Libyan } \\
\text { desert glass; } 34.7 \pm 2 \\
\text { Bediasite; } 38 \pm 9 \text { Popigai } \\
(100 \mathrm{~km}) ; 57 \text { Kara }(50 \mathrm{~km}) \\
\text { Russia }\end{array}$ \\
\hline $\begin{array}{l}12^{\text {th }} \\
\text { biosphere }\end{array}$ & $\begin{array}{l}\text { From } 6 \mathrm{By}-\text { to } \\
\text { present time }\end{array}$ & $\begin{array}{l}\text { Present day geology and geography; maximum biodiversity; } \\
\text { presence of humans }\end{array}$ & $\begin{array}{l}0.77 \pm 0.1 \text { Australites; } 088 \pm \\
0.13 \text { Ivory Coast } \\
\text { Hoyle's (1984) impact - } \\
\text { Pleist.glac.; Impacts } 9700 \mathrm{yr} \text {. } \\
\text { B.P (Tollman and Tollman } \\
\text { 1994) } \\
\end{array}$ \\
\hline
\end{tabular}

lower level/upper level contact zone of the K-T boundary (Table 3). Pollens are more conspicuously different than foraminifera from lower level to upper level. Foraminifera seems to have undergone some transport from lower level to the upper level through erosion (Albertão et al. 1993, Albertão et al. 1994a, 1994b, 1994c, Stinnesbeck and Keller 1995, Koutsoukos 1995).

Ir-anomaly Ir-distribution in sediments points out to an anomaly in the named bed I characterised biostratigraphicaly (Albertão and Martins 1992, Albertão et al. 1992, Albertão 1993) as the last Cretaceous level in Pedreira Poty (quarry) within the basis of Maria
Farinha formation. Ir-content is around 26 times bigger than the average values of all other samples. This anomaly was also confirmed when considered the ratio with clay minerals (Fig. 2). Other recognised world occurrences present similar low values of Ir-anomaly (Donovan et al. 1988, Bourgeois et al. 1988). At the same level (bed I) a TOC (Total Organic Carbon) anomaly was also observed (Fig. 2).

Spherules Microtektite-like microspherules (Fig. 3a) and shattered fragments of shocked-like quartz grains (Fig. 3b) are common immediately underneath and at bed I (Albertão et al. 1994c, Albertão 1997, Delfcio et al. 1998). Microspherules are better 
Table 3 - Palaeontological evidences of the K-T boundary in Poty Quarry, and some geochemical characteristics of transitional layers in PE-PB basin, Brazil.

\begin{tabular}{|c|c|c|c|c|}
\hline $\begin{array}{l}\text { Lower part of the } \\
\text { contact zone }\end{array}$ & Cretaceous Foraminifera & $\begin{array}{l}\text { Extinction of } \\
\text { Pallinomorphs }\end{array}$ & \multicolumn{2}{|c|}{ Contents in ppm } \\
\hline $\begin{array}{l}\text { base of layer } \mathbf{D} \text {; } \\
\text { contact of upper } \\
\text { Gramame fm. / lower } \\
\text { Maria Farinha fm. }\end{array}$ & $\begin{array}{l}\text { Rugoglvoigerina, } \\
\text { Pseudoguembelina palpebra } \\
\text { e carseyae Globotruncana } \\
\text { aegyptiaca, Pseudo } \\
\text { guembelina excolata, etc. }\end{array}$ & $\begin{array}{l}\text { Dinogymnium, } \\
\text { Deflandrea diebeli, } \\
\text { Ariadnaesporites sp. }\end{array}$ & $\begin{aligned} \mathrm{Lu} & \cong 0,4 \\
\mathrm{Hf} & \cong 2,7 \\
\mathrm{Th} & \cong 13 \\
\mathrm{U} & \cong 30 \\
\mathrm{Yb} & \cong 3,8\end{aligned}$ & $\begin{array}{c}\mathrm{Dy} \cong 6,5 \\
\mathrm{Sm} \cong 6,3 \\
\mathrm{Nd} \cong 39,8 \\
\mathrm{Ce} \cong 118,0 \\
\mathrm{Se} \cong 5,0\end{array}$ \\
\hline $\begin{array}{l}\text { Upper part of the } \\
\text { contact zone }\end{array}$ & Tertiary Foraminifera & New palinomorphs & \multicolumn{2}{|c|}{$\begin{array}{c}\text { Content intervals in } \\
\text { ppm }\end{array}$} \\
\hline $\begin{array}{l}\text { Base of overlying layer } \\
\text { to stratum D }\end{array}$ & $\begin{array}{l}\text { G.M.trinidadensis } \\
\text { G.[M.]pseudobul-loides, } \\
\text { G.[P.]eugubina, G.[E.] } \\
\text { fringa, G. minutula }\end{array}$ & \begin{tabular}{|l|} 
Echitriporites \\
trianguliformis, \\
Schizeoisporites \\
eocenicus, \\
Proxaperetites cursus \\
and pollens of palmaceae
\end{tabular} & $\begin{array}{l}\mathrm{Lu} \cong 0,1-0,25 \\
\mathrm{Hf} \cong 0,3-2,0 \\
\mathrm{Th} \cong 1,0-12,0 \\
\mathrm{U} \cong 1,0-15,0 \\
\mathrm{Yb} \cong 0,4-\mathrm{a} 1,8\end{array}$ & $\begin{array}{c}\mathrm{Dy} \cong 0,3-0,4 \\
\mathrm{Sm} \cong 0,2-3,5 \\
\mathrm{Nd} \cong 1,0-18,0 \\
\mathrm{Ce} \cong 1,0-39,0 \\
\mathrm{Se} \cong 0,2-5,0\end{array}$ \\
\hline
\end{tabular}

preserved in bed $\mathrm{D}$, the conspicuous probable tsunamite which occurs under bed I (Albertão and Martins 1996a, Martins and Albertão 1996a, Martins and Albertão 1988), probably due to the low permeability, which avoided recrystallization, devitrification and/ or weathering in bed D. Their composition, shapes, internal and surface textures are similar to those reported elsewhere like those of Caravaca/Spain and Raton basin/USA. Most are $150 \mathrm{~mm}$ across and develop as spheres, or less frequently as oblate spheroids; few as teardrop like. Many have crater-like pits and protruding mounds of various sizes and shapes (Fig. 3a). Their morphic features are similar to those of well-known tektites and micro-tektites (McNamara 1985, Wang 1992). Their outersurface is similar to the main mineral components of the layers they are found within (limestone and marls reworked with phosphate grains of microgastropods, foraminifera and small brownish, oval faecal pellets - microprolites). Diagenetic process has necessarily worked on the spherule outer-surfaces. Spherules can be divided in three distinct classes (Marini et al., in press): (1) resistant class (2) white class (3) brittle class. Most of them are composed mainly by F-rich apatites and differ notably from Al- and Fe- rich phosphate types described elsewhere in the world (Albertão et al., in press). Finally bed D,

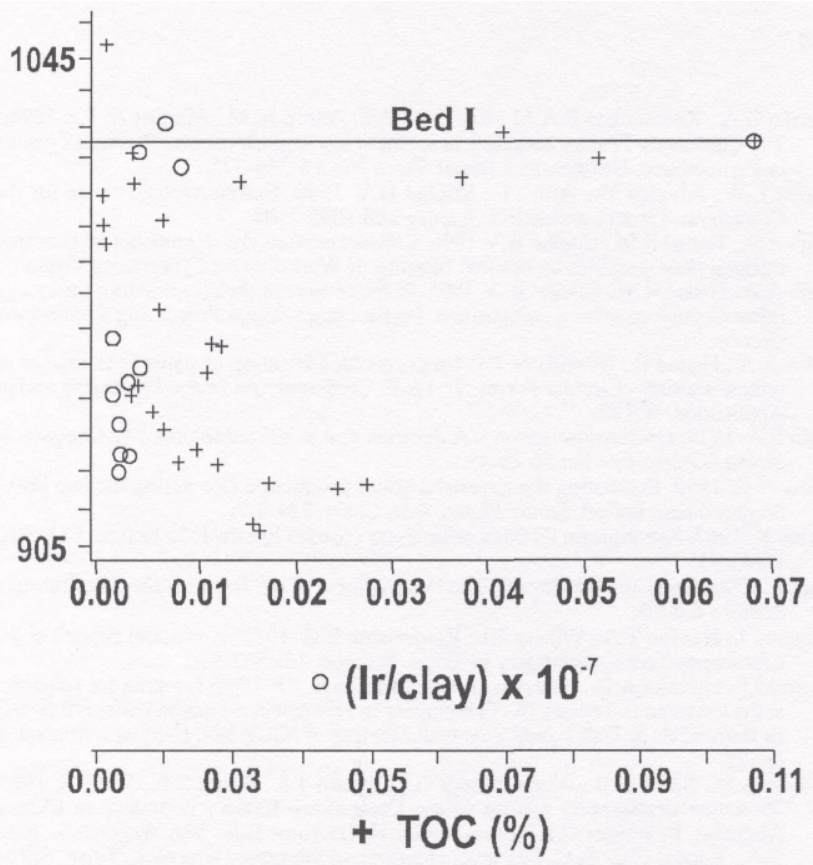

Figure 2 - Distribution of Jr-content across the K-T boundary (neighbourhood of bed I); the ratio Ir/clay clearly indicates the presence or an anomaly; vertical scale is the thickness of outcrops in cm.; distribution of TOC (Total Organic Carbon) across the K-T boundary; here the anomaly is again characterised.

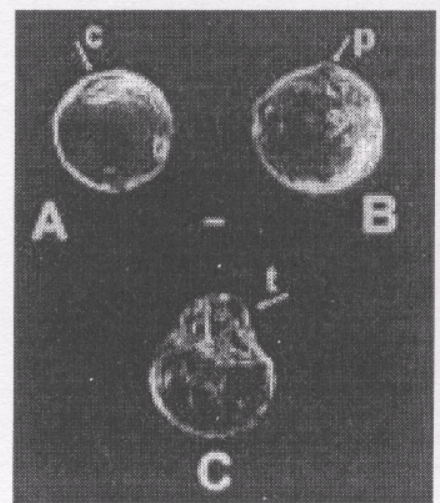

(a)

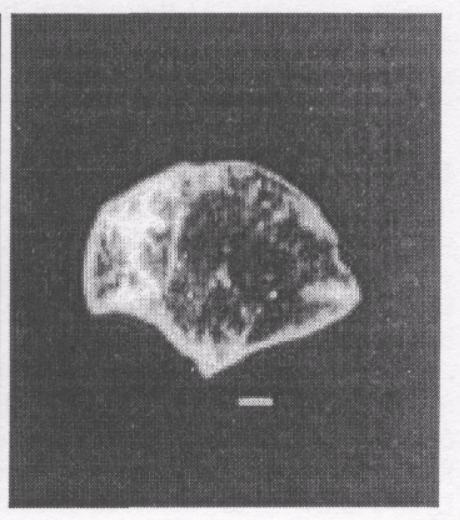

(b)
Figure 3 - (a) - Scanning electron photomicrographs of three selected microspherules present at bed I; structures such as crater-like pits (c), protrusions (p) and tails (t) are present (scale bar $=20 \mathrm{~mm}$ ); (b) photomicrography of a shock-metamorphosed quartz grain from bed $D$, exhibiting intersecting sets of sharp and straight planar lamellae (scale bar$120 \mathrm{~mm}$ ). Photographs (a) and (b) kindly ceded by E. A. M. Koutsoukos (Petrobras/Cenpes).

especially its base not yet fully studied, is the best candidate in holding tektites as a "historicity-attribute" of the $\mathrm{K} /$ pre-T impact event as locally recorded.

CAMPOS BASIN - RIO DE JANEIRO SHELF - PREVIOUS AND NEW INVESTIGATIONS The initial efforts to study the submarine basin of Campos offered only a relative contribution to understand the K-T boundary (Albertão 1993, Albertão and Martins Jr. 1995, Martins Jr. and Albertão 1996b). The sedimentary record permitted to identify distinct behaviour of elements and minerals in the analysed drilling wells suggesting identical sedimentary sources but distinct sedimentary processes. Cyclic deposition of elements is evident (alkaline, earthy alkaline, metals and rare earth - of a total of 46 elements).

Studies based on samples from Campos permitted to identify the K$\mathrm{T}$ boundary with calcareous nannofossils and associated spherules (Grassi, in press, Grassi and De Ros 1999). A 2.5-cm thick layer of spherules was interpreted as tektites derived from the Chicxulub Event. Tektites are dark-grey to black with 0.3 to $1.4 \mathrm{~mm}$ of diameter. Calcite and pyrite extensively substituted them. Some of them display internal features of flow and devitrification textures of the original glass preserved as minor inclusions in only a few tektites. Eventually these tektites are the most faraway deposited material from the local impact crater of Chicxulub as far as $-7,800 \mathrm{~km}$ (Grassi and De Ros 1999 , Albertão et al., in press). 


\section{PERSPECTIVE OF FUTURE RESEARCHES} to shattered fragments of shocked-like quartz grains investigations especially in the boundary layers D and I. Campos basin most certainly can still furnishes a lot of historicity-attributes such as spherules. Other coastal basins may eventually bring more light on this phenomenon as well. Other Brazilian investigators are studying known craters such as Araguainha astrobleme (Hippert and Lana 1998).

Detailed micropaleontological studies (mainly for foraminera, nannofossils, pollens and ostracods) are at present being developed in Ph.D. and M.Sc. thesis under the supervision of Dr. Eduardo A. M. Koutsoukos (Petrobras/Cenpes). Very soon it will bring new data to the interpretation of the boundary events.

A software for KHOROS ambience is already developed. It is possible the automatic recognition of circular forms within the various types of remote sensing images. The program is capable of distinguishing impact craters (fig. 4) from those of volcanoes (Hadad et al. 1998-2000, Araujo et al. 1996, 1998, in press). The program permits the recognition of objects in a scene, as a last step in a processing-chain, which can be described in four phases [i] reading, selection enhancement and registration of images [ii] data fusion and pattern detection [iii] pattern recognition and [iv] identification of the targets - models. At the present time initial researches are being developed in Aymores astrobleme in Minas Gerais State (Martins Jr. et $a l ., 2000)$ and presently research will be conducted for craters systematic identification.

CONCLUSIONS Present time geological thought has been transformed with various paradigm revolutions [plate tectonics, cladist evolution, and catastrophism with its various branches]. Any sort of resistance to recognise the relative importance of the principle of catastrophism on equal basis with the principle of actualism is faded to bankruptcy.

Today we can repeat with more amplitude T.H. Huxley's statement that - "catastrophes are part and parcel of regime" ["periodic catastrophes" like earthquakes and turbidite formation, etc.] and also that - "non-regime catastrophes are part of Earth's history revolutions". Lyell's idiosyncratic denial of catastrophes makes no sense. In a 1998 workshop of the Planetary Society on Impact Hazards Binzel's (1999) ideas concerning a probability measure graphic for impacts on Earth was definitely accepted as the "Torino scale". The Chicxulub Event is

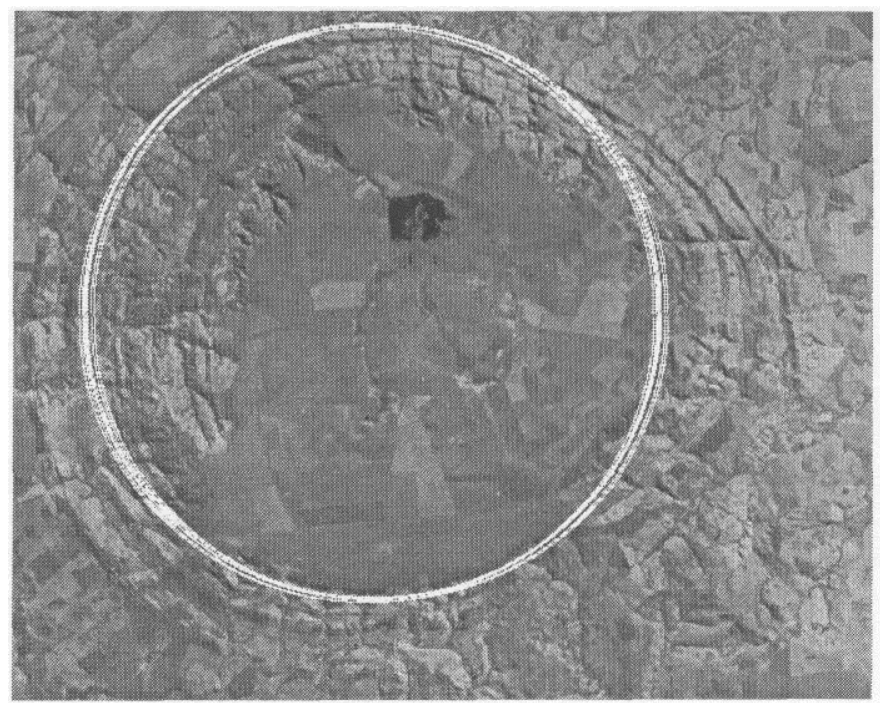

Figure 4 - An example oj contour recognition of a crater [s a tellite Jittered image track 220-73).

included in category 10 in Torino scale - "global/certain collision/ capable of causing a global climatic catastrophe - probability one per 100,000 years".

Acknowledgments To Jorge C. Delia Favera (Rio de Janeiro State University), Eduardo A. M. Koutsoukos (Petrobras/Cenpes), Moses Attrep Jr. (Los Alamos Lab.), Francois Marini (E.N.S.G., Nancy), Maria Paula Delfcio (Ouro Preto Federal University), Alexandre A. Grassi (Petrobras/EPBC) and Antonio Donizeti Oliveira (Ouro Preto Federal University) for their contribution to the researches during the last 10 years, with profitable discussions and/or scientific collaboration; to Andreá da Silva Rosa (XEROX Co., in the support drafting section o Petrobras/EPBC) for the final version of the figures, and to two anonymous referees of RBG for the critical review of the manuscript.

\section{References}

Albertão G.A. 1991. Planeta Terra: um sistema aberto dentro do universe. Bol. Geoc. Petrobras, 5:120-123.

Albertão G.A. 1993. Abordagem interdisciplinar e epistemologica sobre as evidências do limite Cretáceo-Terciário com base em leituras no registro sedimentar das bacias da costa leste brasileira. Dissertação de M.Sc. Ouro Preto. 2 vol. 251 p. cartas e anexos.

Albertão G.A. 1997. The Cretaceous-Tertiary Boundary in Brazil - State of the art and peculiarities. Sphaerula, 1:101-114.

Albertão G. A. \& Martins Jr. P. P. 1992. O evento-limite entre o Cretaceo e o Terciário nas bacias sedimentares brasileiras. In: SBG, Congr. Brasil. Geologia, 37, São Paulo, pp. $463-465$.

Albertão G.A. \& Martins Jr. P.P. 1995. Abordagem estatistica para discriminação geoquimico-estratigráfica de depositos da transição Meso-Cenozoica em bacias costeiras do Brasil. In: Simp. Quantificação em Geociências, Rio Claro, São Paulo, Bol. Resumos Expandidos, pp.3-7.

Albertão G.A. \& Martins Jr. P.P. 1996a. A possible tsunami deposit at the CreteceousTertiary Boundary in Pernambuco, Northeastern Brazil. Sed. Geol. 104:189-201.

Albertão G.A. \& Martins Jr. P.P. 1996b. Stratigraphic record and geochemistry of the Cretaceous-Tertiary (K-T) boundary in Pernambuco/Paraiba, north-eastern Brazil. In: Jardine S, de KlaszH., Debenay J-P (eds.) Geologic de 1'Afrique et de 1'Atlantique Sud, Elf Aquitaine Edition, Memoire 16:403-411.

Albertão G. A., Koutsoukos A.M.E., Regali S.P., Atrep Jr. M., Martins Jr., P. P. 1992. O evento limite do Cretáceo-Terciário e seu registro nas bacias sedimentares brasileiras. Acta Geologica Leopoldensia, 15(36): 163

Albertão G. A., Koutsoukos E.A.M., Regali M.P.S., Martins Jr. P. P. 1993. O registro micropaleontologico com base em foraminíferos no limite Cretaceo-Terciario na bacia de Pernambuco, Nordeste do Brasil. In: Congr. Brasil. Paleontologia/Simp. Micropalentologia, 13, São Leopoldo, Bol. Resumos Expandidos, pp: 54

Albertão G. A., Martins Jr. P.P., Koutsoukos E.A.M. 1994a. O limite Cretaceo-Terciario na bacia de Pernambuco/Paraiba: caracteristicas que definem um marco estratigrafico relacionado a um evento catastrófico de propoções globais. Acta Geologica Leopoldensia 17(39/1 ):203-219.

Albertão G.A., Grassi A.A., Martins Jr. P.P., De Ros L.F. (in press). The K-T boundary in Brazilian sedimentary basins and related spherules. Geochemical Journal.

Albertão G. A., Martins Jr. P. P., Koutsoukos E.A.M. Attrep Jr.,M., Regali M. S. P. 1994b. High resolution stratigraphy across the Cretaceous-Tertiary boundary in Pernambuco, Northeastern Brazil. In: Intern. Congres. Sedimentology, 14, Recife.
Albertão G.A., Koutsoukos E.A.M., Regali M.P.S., Attrep Jr. M., Martins Jr. P.P. 1994c The Cretaceous-Tertiary boundary in southern low-latitude regions. Preliminary study in Pernambuco, Northeastern Brazil. Terra Nova 6:366-375.

Alvarez L.W., Alvarez W., Asaro E, Michel H.V. 1980. Extraterrestrial cause for the Cretaceous-Tertiary extinction. Science 208:1095-1108.

Araujo A. A., Hadad R.M., Coelho B.Y 1996. Enhancement of sketch contours on paintings infrared photographies by optimal filtering. II Workshop on Cybernetics Vision.

Araujo A.A., Hadad R.M., Coelho B. V. 1998. Enhancement of sketch contours on painting infrared photographs: a comparison. In: European Signal Processing Conference, Greece.

Araujo A. A., Hadad R., Martins Jr. P.P. (in press) Identification of patterns in images of remote sensing - Circular Forms. $7^{\text {th }}$ I.E.E. Conference on Image Processing and its Application, IPA99.

Austin S.A. 1979. Uniformitarianism - A doctrine that needs tethinking. The Compass of Sigma Gamma Epsilon 56:29-45.

Barlow N.G. 1990. Estimating the terrestrial crater production rate during the late heavy bombardment Period. Lunar Planet. Inst. Contr. 746:4-7.

Beurlen K. 1967. Estratigrafia da faixa sedimentar costeira Recife-Joao Pessoa. Bol. SBG 16:43-53.

Binzel R. 1999. Assessing the Hazard: The Development of the Torino Scale. The Planetary Society, 6:6-10.

Bourgeois J., Hansen T.A., Wiberg P.L. Kaufamann E.G. 1988. A tsunami deposit at the Cretaceous-Tertiary boundary in Texas. Science, 241:567-570.

Delfcio M.P., Oliveira A.D., Albertão G.A.A, Martins Jr. P.P. 1998. Looking for spherules at the Cretaceous-Tertiary (K-T) boundary in Pernambuco-Parafba basin, NE Brazil. In Detre C.H. \& Toth I. (eds.). Annual Meeting of IGCP 384. Extraits.... Budapest. pp. 28 .

Donovan A.D., Baum G.R., Blechschmidt G.L., Loutit T.S., Pflum C.E., Vail P.R. 1988 Sequence stratigraphy setting of the Cretaceous-Tertiary boundary in Central Alabama. In Wilgus C.K., Posamentier H, Hastings B.S., Van Wagoner J., Ross C.A., Kendal C.G. St.C. Sea-level changes: an integrated approach. Tulsa, SEPM Special Public, $n$. 42

Dott R.H. 1983. SEPM Presidential address: episodic sedimentation - how normal is average? How rare is rare? Does It Matter? Jour, of Sedim. Petrol., 53:5-23.

Fidello F. 1931. Informazione Fides in L' Osservatore Romano. 1 Marzo 1931. pp.5, in La Biblioteca Apostolica Vaticana; see also Daily Herald. 6 March 1931. pp.9. Gould S.J. 1965. Is Uniformitarianism necessary? Am. Jour. Sci., 263:223-228. 
Grassi A.A. 2000. O Limite Cretácio-Tertiário das bacias de Pernambuco-Paraiba e Campos: um estudo multidisciplinar com enfase na bioestratigrafia de nanofósseis calcários. M.Sc. thesis. Universidade Federal do Rio Grande do Sul. Brasil. 238 p.

Grassi A.A. \& De Ros L.F. 1999. Tectitos atribuidos ao ejeto de baixo angulo de Chichulub no Limite Cretacio-Terciario da Bacia de Campos, Brasil. Bol. 50 Simp. Cretáceo do Brasil. Rio Claro. S. Paulo, pp. 681-686.

Grieve R.A.F. 1980. Impact bombardment and its role in protocontinental growth of the early Earth. Precambrian Research, pg. 217-248.

Grieve R.A.F. 1982. The Record of Impact on Earth: Implications for a Major Cretaceous/ Tertiary Impact Event. Geol. Soc. Am. Spec. Publ. 190pp. 25-38

Haddad R., Araujo A.A., Martins Jr. P.P. 1988-2000. Automatic detection of circular structures in various types of images. Belo Horizonte. Fundação CETEC and structures in various types of images. Belo Horizonte. Fundação CEI
Graduate Course on Computation Science - Univ. Fed. Minas Gerais.

Hippert J. \& Lana C. 1998. Aerial crystallization of hematite in impact bombs from the Aragauinha astroblem, Mato Grosso, central Brazil. Meteoritics and Planetary Science, 33:1303-1309.

Hooykaas R. 1970. Catastrophism in geology, its scientific character in relation to actualism and uniformitarianism. In: Albritton Jr. C.C. Philosophy of Geohistory. Benchmark Papers in Geology. Ulsted Press. Wiley and sons Inc. v.13. pp. 310- 356

Hoyle F. 1984. On the Cause of Ice-Ages. Earth, Moon and Planets, 31:229-248.

Huxley T.H. 1869. Anniversary address of the President. Geol. Soc. London Quart. Jour. v. 25, pp. xxxviii-liii.

Koutsoukos E.A.M. 1995. Reply to Stinnesbeck W. and Keller G. The Cretaceous-Tertiary boundary in southern low-latitude: preliminary study in Pernambuco, northeastern boundary in southern low-latitude: preliminary study

LyellC. 1830-1833. Principles of Geology. Being an attempt to explain the former changes of the Earth's surface by reference to causes now in operation. London, Murray, v. I, 1830. 512 p.; v.II, 1832, 330p.; v.III, 1833, 398 p. (in p. 180).

Lyell K.M. 1881. Life letters and journals of Sir Charles Lyell, Bart., London, Murray, 2 v., $475,489 \mathrm{p}$

Mabesoone J.M., Tinoco I.M., Coutinho P.N. 1968. The Mesozoic-Tertiary boundary in northeastern Brazil. Palaeogeogr, Palaeoclim, Palaeoec., 4:161-185.

Marini F, Albertão G.A., Oliveira A.D., Delfcio M.P. (in press). Preliminary SEM and EPMA investigations on KTB spherules from Pernambuco area (NE Brazil): diagenetic apatite and fluorite concretions, suspected fluorine anomalies. Proc. Annual Meet. IGCP 384,1998, Budapest, Hungarian Academy of Science (in press).

Martins Jr. P.P. 1999. Epistemologia das Geociências. Ouro Preto: Apostila Pre-livro. Escola de Minas Graduate Course on Crustal Evolution and Natural Resources M.Sc. and Dr. Sc.

Martins Jr. P.P. \& Albertão G.A. 1996a. A recente evolução do pensamento geologico sobre impactos de meteoros: significado para a história Mesozoico/Cenozoica. Bol. $4^{\circ}$ Simp. Cretáceo no Brasil, Rio Claro. pp. 55-58

Martins Jr. P.P. \& Albertão G.A..1996b. Geochemical aspects of the Cretaceous basins of the South Atlantic western margin in Brazil. IGCP PROJECT no. 381. South Atlantic Mesozoic Correlations. IUGS/UNESCO. SAMC News. (5):38-40

Martins Jr. P.P. \& Albertão G.A. 1998. Identification of catastrophic sedimentary deposits in the stratigraphic record. In: Congr. Brasil. Geologia, 50, Belo Horizonte, Anais, p. 105.
Martins Jr. P.P., Albertão G.A., Delício M.P. 2000. Survey of Aymores Astrobleme in Minas Gerais. Project in Progress (2000-2001). CETEC/UFOP - EM - DEGEO.

Marvin U.B. 1990. Impact and its revolutionary implications for geology, in Sharpton, V.L and Ward, P. D. (eds.) Global catastrophes in Earth history: an interdisciplinary conference on impacts. Volcanism and mass mortality. Boulder, Geol. Soc. America Special Paper, 247:147-154

McNamara K. 1985. Tektites. Western Australia Museum, Perth, pp. 10-17.

Pomerol C. 1984. Des tempestites aux extra-terrestrites: nature, duree, periodicite et interet des evenements en stratigraphie. Bull. Soc. Geol. de France, 7. t. XXVI. n. 6:11651169.

Prevost C. 1825 . De la formation des terrains des environs de Paris. Bull. Sciences Soc. Philomatique. pp. 74-77.

Prevost C. 1845. De la chronologie des terrains et du synchronisme des formations (extrait). Acad. Sci. Comptes Rendues, 20:1062-1071.

Shoemaker E.M. \& Shoemaker C.S. 1990. Proterozoic impact record of Australia. In Int Workshop on Meteoritic Impacts on Early Earth, Perth. Lunar Planet. Inst. Houston Contrib. 647:47-48.

Sircilli Neto F. 1986. Medidas de iridio e o suposto impacto meteoritico do fim do Cretaceo. M.Sc. thesis. Pós-graduação do INPE, São Jose dos Campos. 90 p.

Stinnesbeck W. 1989. Fauna y microflora en el lirnite Cretacico-Terciario en el Estado de Pernambuco, Nordeste de Brasil. Contribuiciones de los Simposios sobre Cretacico de America Latina. Parte A, pp. 215-230.

Stinnesbeck W. \& Keller G. 1995. The Cretaceous-Tertiary boundary in southern low-latitude: preliminary study in Pernambuco, northeastern Brazil - Comments and Reply. Terra Nova, 7:375-382

Termier H. \& Termier G. 1986. La double evolution de la lithosphere et de la biosphere. Geologische Rundschau, 75:863-887.

Tinoco I.M. 1967. Micropaleontologia da faixa sedimentar costeira Recife-João Pessoa. Bol. SBG 16:81-85.

Tollman E.K. \& Tollman A. 1994. The youngest big impact on Earth deduced from geological and historical evidence. Terra Nova, 6:209-217.

Wang K. 1992. Glassy microspherules (microtektites) from an Upper Devonian limestone. Science, 256:1547-1550.

Wilhelms D.E. 1987. The geological history of the Moon. USGS Prof. Paper. 1348. 302p.

\section{Contribution IGC-151
Received March 3,2000 \\ Accepted for publication May 10, 2000}

* en hommage a CARL SAGAN and EUGENE SHOEMAKER, astronomers who are examples for present day and on coming generations of people of science. 